\title{
Water Resources of St. Martin Parish, Louisiana
}

\section{Introduction}

Information concerning the availability, use, and quality of water in St. Martin Parish, Louisiana (fig. 1), is critical for proper water-supply management. The purpose of this fact sheet is to present information that can be used by water managers, parish residents, and others for stewardship of this vital resource. In 2014, about 46.99 million gallons per day (Mgal/d) of water were withdrawn in St. Martin Parish, including about $35.91 \mathrm{Mgal} / \mathrm{d}$ from groundwater sources and $11.08 \mathrm{Mgal} / \mathrm{d}$ from surface-water sources ${ }^{1}$ (table 1) (Collier, 2018). Withdrawals for agricultural use, composed of aquaculture (32.28 Mgal/d), rice irrigation (6.44 Mgal/d), general irrigation $(2.38 \mathrm{Mgal} / \mathrm{d})$, and livestock uses $(0.06 \mathrm{Mgal} / \mathrm{d})$, accounted for about 88 percent $(41.16 \mathrm{Mgal} / \mathrm{d})$ of the total water withdrawn (table 2). Other categories of use included public supply, which

${ }^{1}$ Water-withdrawal data are based on estimated or reported site-specific data and aggregated data, which are distributed to sources. For a full description of water-use estimate methodology, see "Data Collection" in Sargent (2011). Tabulation of numbers in text and tables may result in different totals because of rounding; nonrounded numbers are used for calculation of totals. accounted for about 10 percent $(4.83 \mathrm{Mgal} / \mathrm{d})$, rural domestic, which accounted for about 2 percent $(0.81 \mathrm{Mgal} / \mathrm{d})$, and industry, which accounted for less than 1 percent $(0.18 \mathrm{Mgal} / \mathrm{d})$. Water-use data collected at 5-year intervals from 1960 to 2010 and again in 2014 indicate that water withdrawals in St. Martin Parish peaked in 1985 at more than $68 \mathrm{Mgal} / \mathrm{d}$ (fig. 2) (Sargent, 2011; Collier, 2018).

\section{Groundwater Resources}

St. Martin Parish includes two noncontiguous sections, Upper and Lower, that are separated by Iberia Parish (fig. 1). The Atchafalaya aquifer is the primary aquifer underlying St. Martin Parish. The aquifer truncates or overlies the Chicot aquifer system; these two units are in direct hydraulic connection and usually are considered as one hydrogeologic unit (Harder and others, 1967; Hosman and others, 1970; Milner and Fisher, 2009). The Atchafalaya aquifer is overlain by clay, silt, and interbedded sand that form a surficial confining unit that restricts downward leakage from land surface. The Evangeline aquifer underlies the Chicot aquifer system but contains little fresh groundwater in St. Martin Parish (fig. 3). The base of fresh groundwater generally ranges from 200 to 900 feet (ft) below the

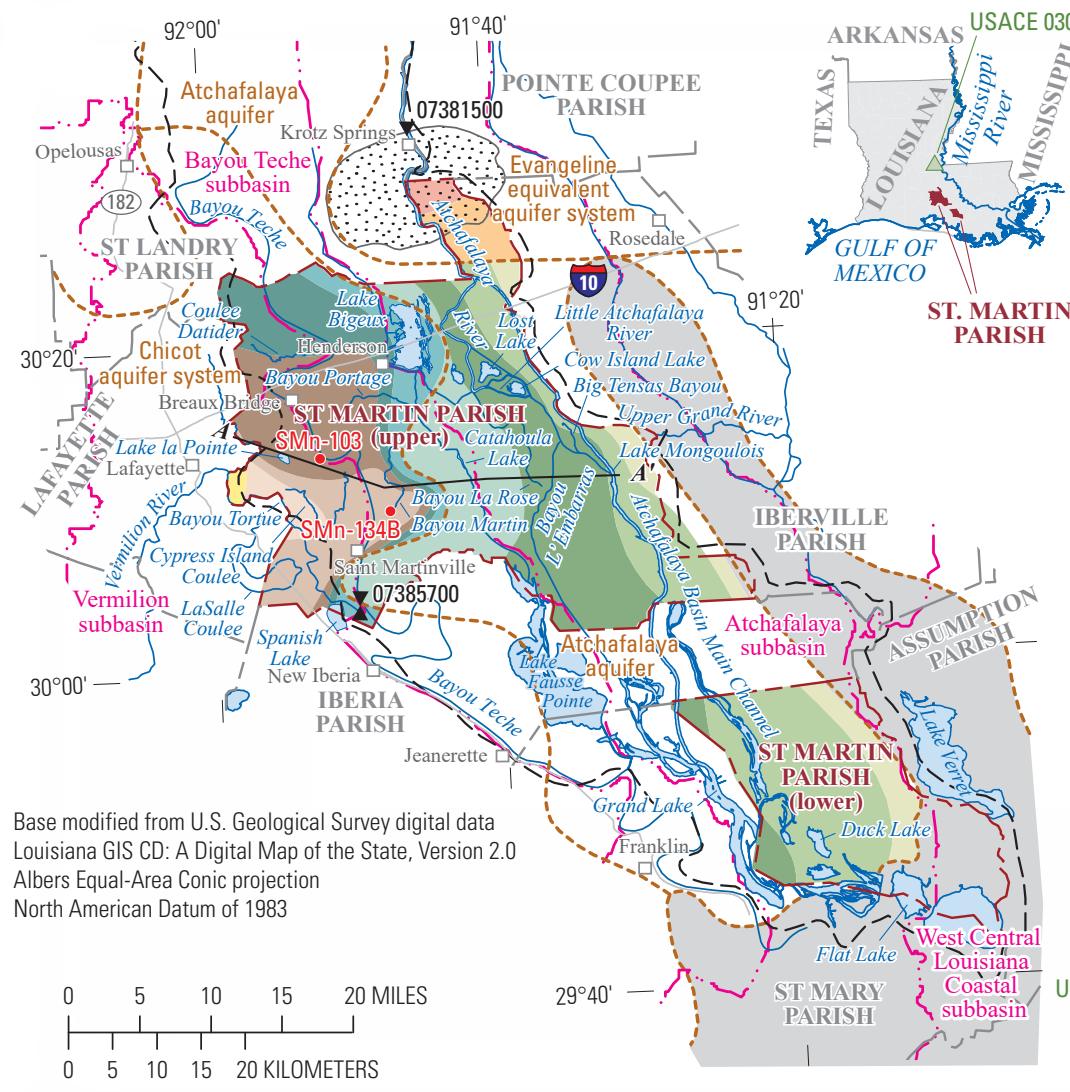

\section{EXPLANATION}

Approximate altitude of base of fresh groundwater, in feet below National Geodetic Vertical Datum of 1929 (NGVD 29) (modified from Smoot, 1988)-Deepest freshwater contained within the Chicot aquifer system, except where noted 100 to 199 200 to 299 300 to 399

400 to 499

500 to 599

600 to 699

700 to 799

800 to 899

900 to 999

1,000 to 1,499

1,500 to 1,999

2,000 and deeper

Approximate area where no major aquifer contains freshwater (modified from Cardwell and others, 1965; Smoot, 1988; Nyman, 1989)

Area where saltwater is present in some sands above base of fresh groundwater (modified from Smoot, 1988)

Approximate boundary of area showing deepest freshwater contained within the overlying Atchafalaya aquifer and the underlying Evangeline equivalent aquifer system (modified from Cardwell and others, 1965; Harder and others, 1967; Smoot, 1988; Nyman, 1989)

Approximate extent of Atchafalaya aquifer (modified from Saucier, 1994; Milner and Fisher, 2009)

- ..- River subbasin boundary

$A-A^{\prime}$ Line of section (see fig. 3; Harder and others, 1967)

SMn-103 Well for which hydrograph is shown (see fig. 4)

$\triangle \quad$ U.S. Army Corps of Engineers (USACE) surface-water SACE 03045 streamflow site and number

U.S. Geological Survey surface-water streamflow site and number

$\checkmark \quad$ U.S. Geological Survey surface-water-quality site and number $07381500 \quad$ (see table 4)

Figure 1. Location of study area, St. Martin Parish, Louisiana. 
Table 1. Water withdrawals, in million gallons per day, by source in St. Martin Parish, Louisiana, 2014 (Collier, 2018).

\begin{tabular}{lcc}
\hline \multicolumn{1}{c}{\begin{tabular}{c}
\multicolumn{1}{c}{$\begin{array}{c}\text { Aquifer or } \\
\text { surface-water body }\end{array}$} \\
Chicot aquifer system
\end{tabular}} & $\begin{array}{c}\text { Ground- } \\
\text { water }\end{array}$ & $\begin{array}{c}\text { Surface } \\
\text { water }\end{array}$ \\
Atchafalaya aquifer ${ }^{1}$ & 4.22 & \\
Bayou Portage & 31.70 & \\
Bayou Teche & & 2.29 \\
Miscellaneous surface-water bodies & & 2.29 \\
\cline { 2 - 3 } Total & $\mathbf{3 5 . 9 1}$ & $\mathbf{1 1 . 0 8}$ \\
\hline${ }^{1}$ Grouped with Mississippi River alluvial aquifer in water-use data.
\end{tabular}

Table 2. Water withdrawals, in million gallons per day, by use category in St. Martin Parish, Louisiana, 2014 (Collier, 2018).

\begin{tabular}{lccc}
\hline \multicolumn{1}{c}{ Use category } & Groundwater & $\begin{array}{c}\text { Surface } \\
\text { water }\end{array}$ & Total \\
\hline Public supply & 4.83 & 0.00 & 4.83 \\
Industry & 0.18 & 0.00 & 0.18 \\
Rural domestic & 0.81 & 0.00 & 0.81 \\
Livestock & 0.05 & 0.01 & 0.06 \\
Rice irrigation & 0.52 & 5.93 & 6.44 \\
General irrigation & 0.48 & 1.90 & 2.38 \\
Aquaculture & 29.05 & 3.23 & 32.28 \\
\cline { 2 - 4 } Total & $\mathbf{3 5 . 9 1}$ & $\mathbf{1 1 . 0 7}$ & $\mathbf{4 6 . 9 9}$ \\
\hline
\end{tabular}

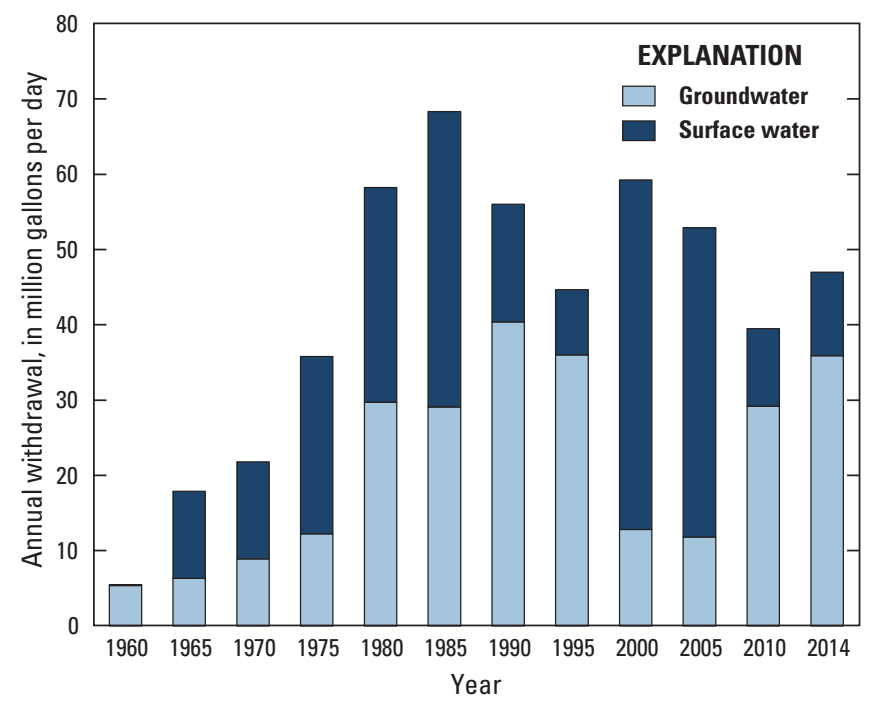

Figure 2. Water withdrawals in St. Martin Parish, Louisiana, 1960-2014 (Sargent, 2011; Collier, 2018).

National Geodetic Vertical Datum of 1929 (NGVD 29) in Upper St. Martin Parish, with a deepening trend from east to west. Fresh groundwater extends to about 2,000 ft below NGVD 29 within a small area near the border with Pointe Coupee and St. Landry Parishes, but saltwater is present in intermediate sands. In Lower St. Martin Parish, fresh groundwater can be found as deep as 200 to $300 \mathrm{ft}$ below NGVD 29 but is absent in the southwestern area (fig. 1).

\section{Atchafalaya Aquifer}

The Atchafalaya aquifer is composed of gravelly deposits that filled scours made on the Mississippi River floodplain (Milner and Fisher, 2009). The Atchafalaya aquifer is difficult to separate from the adjacent and underlying Chicot aquifer system because of similar sediment composition, and the two are often considered as one hydrogeologic unit (Harder and others, 1967; Hosman and others, 1970; Milner and Fisher, 2009). The top of the Atchafalaya aquifer is defined by the base of the surficial confining unit. The thickness of the surficial confining unit ranges from 40 to $160 \mathrm{ft}$ in Upper St. Martin Parish, and generally increases in a northwest to southeast direction (Sargent, 2004). The approximate western extent of the Atchafalaya aquifer is near the western margin of Upper St. Martin Parish (fig. 1) (Milner and Fisher, 2009).

Water levels in the Atchafalaya aquifer are affected by the stage of the Atchafalaya River (Nyman, 1984) and may be locally affected by groundwater withdrawals for aquaculture in St. Martin Parish (table 2), primarily crawfish farming. Crawfish ponds are flooded each year using groundwater and surface-water sources, and pond levels are maintained through the growing season of September through May (Lovelace, 1994). In 2014, a total of $29.05 \mathrm{Mgal} / \mathrm{d}$ of water was withdrawn from the Atchafalaya aquifer for aquaculture in St. Martin Parish (Collier, 2018). Limited data are available to establish current water levels in the Atchafalaya aquifer across the parish. From January 16, 1990, through September 1, 1992, 28 waterlevel measurements were taken at 27 wells across the western half of Upper St. Martin Parish. Water levels ranged from $15 \mathrm{ft}$ above NGVD 29 to $24 \mathrm{ft}$ below NGVD 29. Well SMn-103, which is screened in the Atchafalaya aquifer, exhibited seasonal fluctuations of about $5 \mathrm{ft}$ during its period of record (fig. 4).

State well-registration records listed 1,272 active water wells screened in the Atchafalaya aquifer in St. Martin Parish in 2017: 968 domestic wells, 206 irrigation wells, 68 public-supply wells, and 30 industrial wells. Well depths ranged from 10 to $280 \mathrm{ft}$ below land surface, and reported yields ranged from 3 to 5,000 gallons per minute (gal/min) (Louisiana Department of Natural Resources, 2017). In 2014, about $31.70 \mathrm{Mgal} / \mathrm{d}$ of groundwater were withdrawn from the Atchafalaya aquifer in St. Martin Parish (table 1), with most used for aquaculture (29.05 Mgal/d). Other uses included public supply $(0.92 \mathrm{Mgal} / \mathrm{d})$, rural domestic $(0.62 \mathrm{Mgal} / \mathrm{d})$, rice irrigation $(0.46 \mathrm{Mgal} / \mathrm{d})$, general irrigation $(0.43 \mathrm{Mgal} / \mathrm{d})$, industry (0.17 Mgal/d), and livestock (0.04) (Collier, 2018).

\section{Chicot Aquifer System}

Across most of St. Martin Parish, the Chicot aquifer system underlies the Atchafalaya aquifer (fig. 3) and is composed of thick sand and gravel deposits that thicken in a gulfward direction. The base of the Chicot aquifer system ranges from about $300 \mathrm{ft}$ below NGVD 29 in the northeastern corner of Upper St. Martin Parish to about 1,130 ft below NGVD 29 at the south-central border of Upper St. Martin Parish (Harder and others, 1967). In some areas, the aquifer system forms two discrete sandy units separated by clay. Where this clay is present, the Chicot aquifer system is differentiated into an "upper" and "lower" sand unit (fig. 3).

Regional historical water-level trends indicate a net movement of water in the Chicot aquifer system from the Atchafalaya Basin towards pumping centers in St. Landry, Evangeline, and Acadia Parishes, where water levels in the Chicot aquifer system had declined to $70 \mathrm{ft}$ below NGVD 29 in June 2000 (Lovelace and others, 2004). Well SMn-134B, which is screened in the lower sand unit of the Chicot aquifer system, shows seasonal water-level fluctuations as well as a long-term decline of approximately $0.2 \mathrm{ft}$ per year between 1975 and 2015 (fig. 4). The Chicot aquifer system contains no fresh groundwater in Lower St. Martin Parish, where fresh groundwater is only present in the Atchafalaya aquifer (Smoot, 1988). 


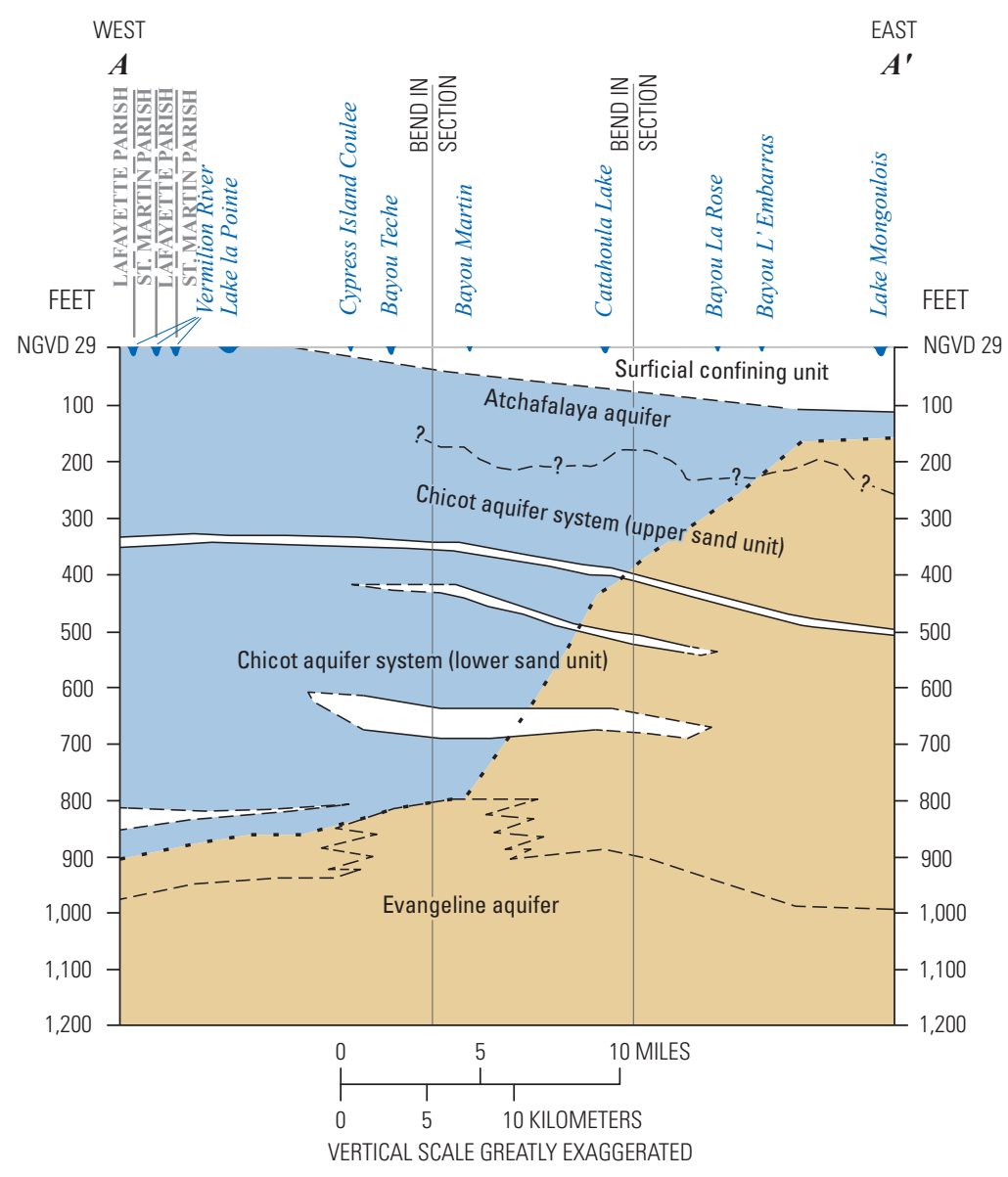

EXPLANATION

Hydrogeologic unit (modified from Harder and others, 1967)

Aquifer containing freshwater-Freshwater contains a chloride concentration of 250 milligrams per liter or less

Aquifer containing saltwater

Confining unit

Hydrogeologic contact (modified from Harder and others, 1967) — Separates hydrogeologic units. Dashed where inferred. Queried where uncertain

- - - Approximate freshwater/saltwater interface (modified from Harder and others, 1967)

Generalized surface profile

NGVD 29, National Geodetic Vertical Datum of 1929

Figure 3. Idealized west-to-east hydrogeologic section through St. Martin Parish, Louisiana, showing aquifer and confining unit intervals (individual sand and clay layers not shown). Modified from Harder and others (1967). Trace of section shown on figure 1.

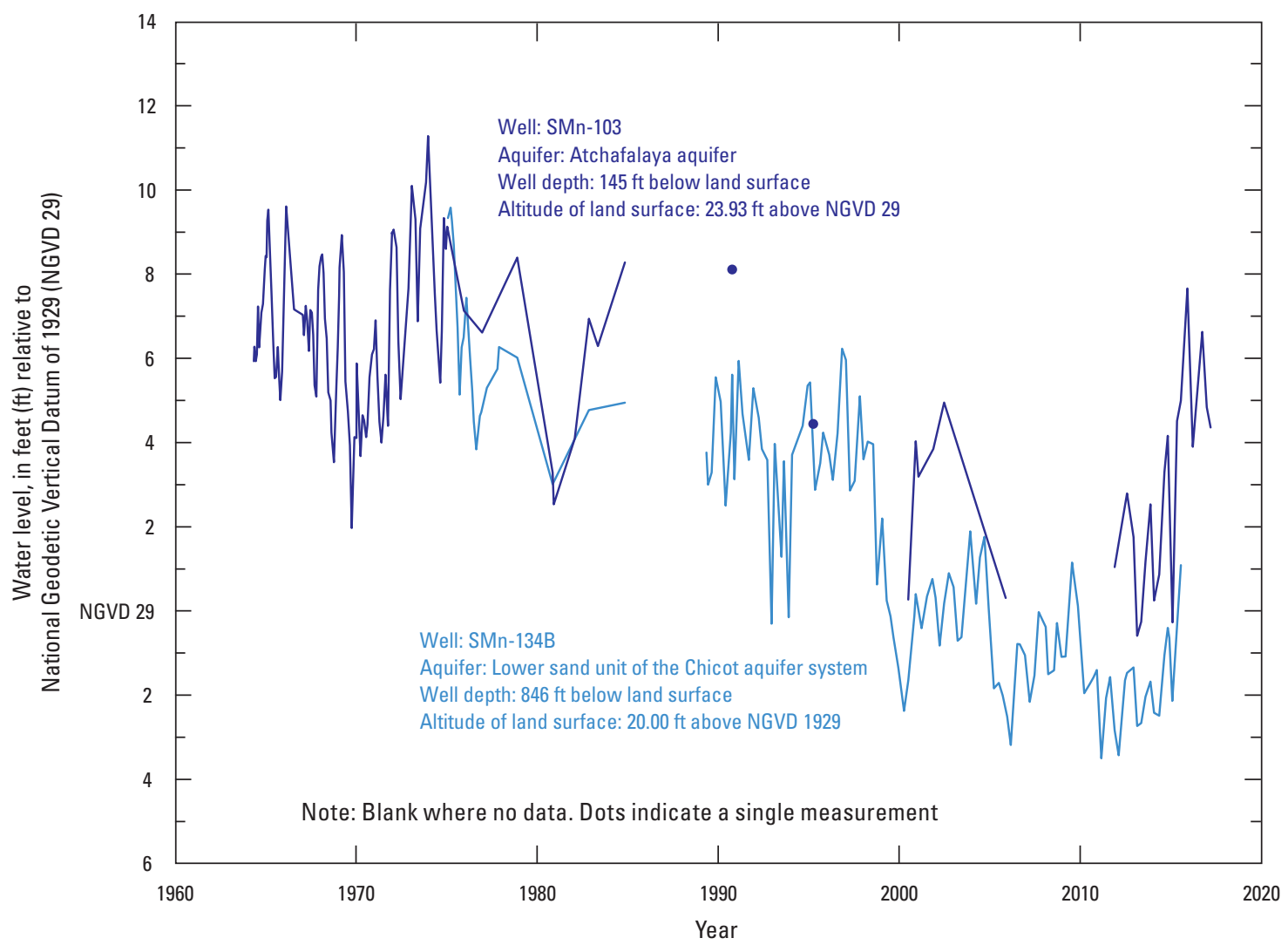

Figure 4. Water levels in wells SMn-103 screened in the Atchafalaya aquifer and SMn-134B screened in the lower sand unit of the Chicot aquifer system, St. Martin Parish, Louisiana (see fig. 1 for well locations; U.S. Geological Survey, 2018). 
State well-registration records listed 359 active wells screened in the Chicot aquifer system in St. Martin Parish in 2017: 270 domestic wells, 57 public-supply wells, 24 irrigation wells, and 8 industrial wells. Wells depths ranged from 65 to $912 \mathrm{ft}$ below land surface, and reported yields ranged from 5 to $4,050 \mathrm{gal} / \mathrm{min}$. Of these 359 wells, 348 were screened in the upper sand unit of the aquifer system (Louisiana Department of Natural Resources, 2017). About 4.22 Mgal/d were withdrawn from the Chicot aquifer system in 2014 in St. Martin Parish, with about 93 percent (3.91 Mgal/d) of the withdrawals used for public supply. The remaining 7 percent $(0.30 \mathrm{Mgal} / \mathrm{d})$ was used for industry, rural domestic use, livestock, rice irrigation, and general irrigation (Collier, 2018).

\section{Groundwater Quality}

Samples of groundwater were collected during 1963-2010 from 33 wells screened in the lower sand unit of the Chicot aquifer system and during 1941-83 from 29 wells screened in the Atchafalaya aquifer as part of an ongoing program to monitor the State's groundwater resources (U.S. Geological Survey [USGS], 2018). Median values for $\mathrm{pH}$ and sulfate concentrations in both aquifers were within or below the U.S. Environmental Protection Agency's Secondary Maximum Contaminant Levels ${ }^{2}$ (SMCLs) (table 3). The median hardness values of 240 milligrams per liter $(\mathrm{mg} / \mathrm{L})$ for the Atchafalaya aquifer and $36.5 \mathrm{mg} / \mathrm{L}$ for the Chicot aquifer system were within the very

${ }^{2}$ The SMCLs are Federal guidelines regarding cosmetic effects (such as tooth or skin discoloration), aesthetic effects (such as taste, odor, or color), or technical effects (such as damage to water equipment or reduced effectiveness of treatment for other contaminants) of potential constituents of drinking water. SMCLs were established as guidelines by the U.S. Environmental Protection Agency (2016). hard ${ }^{3}$ range and the soft range, respectively. Iron and manganese concentrations exceeded the SMCLs of 300 micrograms per liter $(\mu \mathrm{g} / \mathrm{L})$ for iron and $50 \mu \mathrm{g} / \mathrm{L}$ for manganese in about 50 percent of samples from the Chicot aquifer system. Concentrations of iron in all samples from the Atchafalaya aquifer exceeded the SMCL, and concentrations of manganese exceeded the SMCL in 83 percent of the samples from the Atchafalaya aquifer. Samples from the Chicot aquifer system contained higher chloride concentrations than samples from the Atchafalaya aquifer, with median concentrations of 185 and $16 \mathrm{mg} / \mathrm{L}$, respectively. Samples from the Chicot aquifer system had higher dissolved-solids concentrations, with 69 percent of the samples exceeding the SMCL of $500 \mathrm{mg} / \mathrm{L}$ compared to only 23 percent of the samples from the Atchafalaya aquifer exceeding the SMCL.

\section{Surface-Water Resources}

Surface-water resources in St. Martin Parish are present in three main drainage subbasins that drain in a southerly direction: the Atchafalaya subbasin (Hydrologic Unit Code [HUC] 08080101), the Bayou Teche subbasin (HUC 08080102), and the Vermilion subbasin (HUC 08080103) (fig. 1). A small area in Lower St. Martin Parish is drained by the West Central Louisiana Coastal subbasin (HUC 08090302). In 2014, 11.07 Mgal/d of surface water were withdrawn within St. Martin Parish: about $5.93 \mathrm{Mgal} / \mathrm{d}$ for rice irrigation, 3.23 Mgal/d for aquaculture, $1.90 \mathrm{Mgal} / \mathrm{d}$ for general irrigation, and $0.01 \mathrm{Mgal} / \mathrm{d}$ for livestock (table 2) (Collier, 2018).

${ }^{3}$ Hardness ranges, expressed as milligrams per liter of calcium carbonate, are as follows: 0-60, soft; 61-120, moderately hard; 121-180, hard; greater than 180 , very hard (Hem, 1985).

Table 3. Summary of selected water-quality characteristics for samples from 33 wells screened in the lower sand unit of the Chicot aquifer system and 29 wells screened in the Atchafalaya aquifer in St. Martin Parish, Louisiana (U.S. Geological Survey, 2018).

[Values are in milligrams per liter, except as noted. ${ }^{\circ} \mathrm{C}$, degrees Celsius; $\mathrm{PCU}$, platinum cobalt units; $\mu \mathrm{S} / \mathrm{cm}$, microsiemens per centimeter; SU, standard unit; $\mathrm{CaCO}_{3}$, calcium carbonate; $\mu \mathrm{g} / \mathrm{L}$, micrograms per liter; SMCL, Secondary Maximum Contaminant Level established by the U.S. Environmental Protection Agency (2016); NA, not applicable]

\begin{tabular}{|c|c|c|c|c|c|c|c|c|c|c|c|c|c|}
\hline & $\begin{array}{l}\text { Temper- } \\
\text { ature } \\
\left({ }^{\circ} \mathrm{C}\right)\end{array}$ & $\begin{array}{l}\text { Color } \\
\text { (PCU) }\end{array}$ & $\begin{array}{c}\text { Specific } \\
\text { conduc- } \\
\text { tance, } \\
\text { field } \\
(\mu \mathrm{S} / \mathrm{cm} \\
\left.\text { at } 25^{\circ} \mathrm{C}\right)\end{array}$ & $\begin{array}{l}\mathrm{pH}, \\
\text { field } \\
\text { (SU) }\end{array}$ & $\begin{array}{c}\text { Hard- } \\
\text { ness } \\
\text { (as } \\
\mathrm{CaCO}_{3} \text { ) }\end{array}$ & $\begin{array}{l}\text { Cal- } \\
\text { cium, } \\
\text { filtered } \\
\text { (as Ca) }\end{array}$ & $\begin{array}{l}\text { Mag- } \\
\text { nesium, } \\
\text { filtered } \\
\text { (as Mg) }\end{array}$ & $\begin{array}{l}\text { Sodium, } \\
\text { filtered } \\
\text { (as Na) }\end{array}$ & $\begin{array}{l}\text { Chlo- } \\
\text { ride, } \\
\text { filtered } \\
\text { (as CI) }\end{array}$ & $\begin{array}{l}\text { Sulfate, } \\
\text { filtered } \\
\text { (as } \mathrm{SO}_{4} \text { ) }\end{array}$ & $\begin{array}{c}\text { Iron, } \\
\text { filtered, } \\
\text { in } \mu \mathrm{g} / \mathrm{L} \\
\text { (as Fe) }\end{array}$ & $\begin{array}{c}\text { Man- } \\
\text { ganese, } \\
\text { filtered, } \\
\text { in } \mu g / L \\
\text { (as Mn) }\end{array}$ & $\begin{array}{l}\text { Dis- } \\
\text { solved } \\
\text { solids, } \\
\text { filtered }\end{array}$ \\
\hline \multicolumn{14}{|c|}{ Chicot aquifer system (lower sand unit), 33 wells (1963-2010) } \\
\hline Median & 23.8 & 10 & 1,250 & 8 & 36.5 & 10 & 4.1 & 180 & 185 & 1 & 305 & 45 & 582 \\
\hline 10th percentile & 21.6 & 0 & 697.2 & 7.1 & 17.7 & 4.5 & 0.9 & 88 & 34 & 0.2 & 98 & 11 & 419 \\
\hline 90th percentile & 25 & 27.4 & 2,106 & 8.4 & 200 & 44.9 & 17.7 & 388 & 410.9 & 4.2 & 1,310 & 109 & 1,020 \\
\hline Number of samples & 22 & 31 & 43 & 42 & 46 & 30 & 30 & 31 & 56 & 31 & 38 & 30 & 29 \\
\hline $\begin{array}{l}\text { Percentage of } \\
\text { samples that do not } \\
\text { exceed SMCLs }\end{array}$ & NA & 71 & NA & 95 & NA & NA & NA & NA & 66 & 100 & 50 & 53 & 31 \\
\hline \multicolumn{14}{|c|}{ Atchafalaya aquifer, 29 wells (1941-83) } \\
\hline Median & 21 & 10 & 760 & 7.1 & 240 & 69 & 22.5 & 25 & 16 & 2 & 3,050 & 105 & 402 \\
\hline 10th percentile & 20.8 & 3 & 509 & 6.8 & 180 & 46 & 12.9 & 14.4 & 6.0 & 0.28 & 820 & 30 & 341 \\
\hline 90th percentile & 22 & 200 & 838 & 8 & 370 & 98 & 38.5 & 108.8 & 34.5 & 7.36 & 8,370 & 360 & 559.4 \\
\hline Number of samples & 45 & 15 & 79 & 19 & 29 & 14 & 14 & 13 & 90 & 23 & 10 & 6 & 13 \\
\hline $\begin{array}{l}\text { Percentage of } \\
\text { samples that do not } \\
\text { exceed SMCLs }\end{array}$ & NA & 67 & NA & 100 & NA & NA & NA & NA & 99 & 100 & 0 & 17 & 77 \\
\hline SMCLs & NA & 15 & NA & $6.5-8.5$ & NA & NA & NA & NA & 250 & 250 & 300 & 50 & 500 \\
\hline
\end{tabular}




\section{Atchafalaya Subbasin}

The Atchafalaya subbasin covers more than a third of Upper St. Martin Parish on the eastern side, and most of Lower St. Martin Parish (fig. 1). Major streams in the subbasin include the Atchafalaya River, the Upper Grand River, the Little Atchafalaya River, Big Tensas Bayou, Bayou La Rose, and Bayou L'Embarras. Several lakes are present in Upper St. Martin Parish, including Lake Bigeux, Lost Lake, and Cow Island Lake. In Lower St. Martin Parish, lakes within the subbasin include Flat Lake, Duck Lake, and Grand Lake.

Within the Atchafalaya subbasin, the Atchafalaya River and its associated swampland support various commercial and recreational activities, including fishing and hunting. Additionally, its floodplain provides an outlet for the floodwaters of the Mississippi River by way of a series of locks, pumping stations, and drainage structures. A percentage of streamflow (averaging 25 percent for the period 19842007; Kroes and Kraemer, 2013) is diverted from the Mississippi River to the Atchafalaya Basin through the Old River Control Structure. Springtime flooding of the Atchafalaya River maintains the habitat of diverse plants and wildlife that live in the basin's wetlands and swamps, and these ecosystems are monitored by the U.S. Army Corps of Engineers (U.S. Army Corps of Engineers, 2007). The daily average streamflow of the Atchafalaya River during 1963-2016 was 225,520 cubic feet per second $\left(\mathrm{ft}^{3} / \mathrm{s}\right)$ at Simmesport, Louisiana (U.S. Army Corps of Engineers gage number 03045; fig. 1, index map). During this period, the highest monthly average streamflow was $342,173 \mathrm{ft}^{3} / \mathrm{s}$ in May, and the lowest was $108,526 \mathrm{ft}^{3} / \mathrm{s}$ in September.

\section{Bayou Teche Subbasin}

The Bayou Teche subbasin covers approximately the central third of Upper St. Martin Parish (fig. 1). Major streams within the subbasin include Bayou Portage, Bayou Martin, and Bayou Teche; Bayou Teche defines the western margin of the subbasin. The annual average streamflow of Bayou Teche at Keystone Lock and Dam near St. Martinville, Louisiana (USGS site number 07385700 , fig. 1) was $478 \mathrm{ft}^{3} / \mathrm{s}$ during 1960-2014. For this period, the highest monthly average streamflow was $697 \mathrm{ft}^{3} / \mathrm{s}$ in January, and the lowest was $336 \mathrm{ft}^{3} / \mathrm{s}$ in August (USGS, 2018). In 2014, $2.29 \mathrm{Mgal} / \mathrm{d}$ were withdrawn from Bayou Teche in St. Martin Parish, with $1.48 \mathrm{Mgal} / \mathrm{d}$ used for rice irrigation and $0.81 \mathrm{Mgal} / \mathrm{d}$ used for aquaculture (Collier, 2018).

\section{Vermilion Subbasin}

The Vermilion subbasin drains an area along the western margin of Upper St. Martin Parish. Water bodies within this subbasin in the parish include Cypress Island Coulee, Lake la Pointe, Coulee Datider, LaSalle Coulee, Spanish Lake, Bayou Tortue, and small segments of the Vermilion River.

\section{Surface-Water Quality}

Water samples were collected from Bayou Teche at Keystone Lock and Dam near St. Martinville (USGS site number 07385700) during 1965-98 and from the Atchafalaya River at Krotz Springs

Table 4. Summary of selected water-quality characteristics for samples from Bayou Teche at Keystone Lock and Dam near St. Martinville and the Atchafalaya River at Krotz Springs, Louisiana (U.S. Geological Survey, 2018).

[Values are in milligrams per liter, except as noted. ${ }^{\circ} \mathrm{C}$, degrees Celsius; $\mathrm{PCU}$, platinum cobalt units; $\mu \mathrm{S} / \mathrm{cm}$, microsiemens per centimeter; $\mathrm{SU}$, standard unit; $\mathrm{CaCO}_{3}$, calcium carbonate; $\mu \mathrm{g} / \mathrm{L}$, micrograms per liter; SMCL, Secondary Maximum Contaminant Level established by the U.S. Environmental Protection Agency (2016); NA, not applicable; ND, no data]

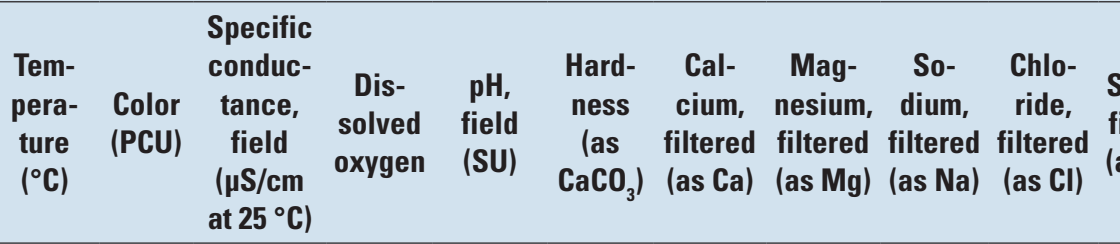

\begin{tabular}{|c|c|c|}
\hline tered & $\begin{array}{c}\text { Iron, } \\
\text { fil- } \\
\text { tered, } \\
\text { in } \mu \mathrm{g} / \mathrm{L} \\
\text { (as Fe) }\end{array}$ & $\begin{array}{c}\text { Man- } \\
\text { ganese, } \\
\text { filtered, } \\
\text { in } \mu \mathrm{g} / \mathrm{L}\end{array}$ \\
\hline
\end{tabular}

Bayou Teche at Keystone Lock and Dam near St. Martinville (1965-98)

\begin{tabular}{|c|c|c|c|c|c|c|c|c|c|c|c|c|c|c|}
\hline Median & 22.5 & 80 & 151 & 6.0 & 7.1 & 45.9 & 11 & 4.4 & 10.5 & 13 & 7.6 & 140 & 47 & 99 \\
\hline 10 th percentile & 11 & 20 & 97 & 3.8 & 6.4 & 28.5 & 7 & 2.6 & 5.8 & 7.9 & 3.9 & 11.4 & 20 & 64.2 \\
\hline 90th percentile & 30 & 120 & 398.2 & 8.8 & 7.6 & 118 & 28.5 & 11 & 30.7 & 39 & 27 & 359 & 126 & 230 \\
\hline Number of samples & 141 & 137 & 145 & 138 & 144 & 144 & 144 & 144 & 142 & 143 & 144 & 76 & 73 & 141 \\
\hline $\begin{array}{l}\text { Percentage of } \\
\text { samples that } \\
\text { do not exceed } \\
\text { SMCLs }\end{array}$ & NA & 8 & NA & NA & 88 & NA & NA & NA & NA & 100 & 100 & 86 & 58 & 100 \\
\hline
\end{tabular}

\begin{tabular}{|c|c|c|c|c|c|c|c|c|c|c|c|c|c|c|}
\hline \multicolumn{15}{|c|}{ Atchafalaya River at Krotz Springs $(1952-72)^{2}$} \\
\hline Median & 20.8 & 15 & 396 & ND & 7.7 & 130 & 37 & 9.5 & 23 & 36 & 48 & ND & ND & 251 \\
\hline 10th percentile & 9.8 & 5 & 280.2 & ND & 6.9 & 94.7 & 28 & 5.6 & 14 & 18 & 27 & ND & ND & 169 \\
\hline 90th percentile & 29.5 & 40 & 540.8 & ND & 8.1 & 180 & 49.6 & 14 & 40 & 70 & 71 & ND & ND & 357.2 \\
\hline Number of samples & 68 & 194 & 113 & ND & 203 & 116 & 113 & 113 & 87 & 203 & 203 & ND & ND & 196 \\
\hline $\begin{array}{l}\text { Percentage of } \\
\text { samples that } \\
\text { do not exceed } \\
\text { SMCLs }\end{array}$ & NA & 61 & NA & ND & 99 & NA & NA & NA & NA & 100 & 100 & ND & ND & 99 \\
\hline SMCLs & NA & 15 & NA & NA & $6.5-8.5$ & NA & NA & NA & NA & 250 & 250 & 300 & 50 & 500 \\
\hline
\end{tabular}

${ }^{1}$ U.S. Geological Survey site number 07385700 (see fig. 1).

${ }^{2}$ U.S. Geological Survey site number 07381500 (see fig. 1). 
(USGS site number 07381500) during 1952-72 as part of an ongoing program to monitor the State's surface-water resources (USGS, 2018) (fig. 1). Median values for $\mathrm{pH}$ and for chloride, sulfate, and dissolvedsolids concentrations were within or below their respective SMCLs (table 4). Median hardness values were within the soft range for Bayou Teche and within the hard range for the Atchafalaya River. The median dissolved-oxygen concentration at Bayou Teche was $6.0 \mathrm{mg} / \mathrm{L}$; $5 \mathrm{mg} / \mathrm{L}$ is considered the minimum value for a diverse population of fresh, warmwater biota, including sport fish (Louisiana Department of Environmental Quality, 2008). The SMCL for color of 15 platinum cobalt units was exceeded in 92 percent of samples from Bayou Teche and 39 percent of samples from the Atchafalaya River. Manganese concentrations were within the SMCL for 58 percent of the samples from Bayou Teche, with a median concentration of $47 \mu \mathrm{g} / \mathrm{L}$.

\section{References Cited}

Cardwell, G.T., Sloss, R., and Duncan, A.C., 1965, Water, in Assumption Parish resources and facilities: Louisiana Department of Public Works and Assumption Parish Development Board, p. 25-38.

Collier, A.L., 2018, Water withdrawals by source and category in Louisiana Parishes, 2014-2015: U.S. Geological Survey data release, https://doi. org/10.5066/F78051VM.

Harder, A.H., Kilburn, C., Whitman, H.M., and Rogers, S.M., 1967, Effects of ground-water withdrawals on water levels and saltwater encroachment in southwestern Louisiana: Louisiana Geological Survey Department of Conservation and Louisiana Department of Public Works Water Resources Bulletin no. 10, $56 \mathrm{p}$.

Hem, J.D., 1985, Study and interpretation of the chemical characteristics of natural water (3d ed.): U.S. Geological Survey Water-Supply Paper 2254, 264 p., accessed October 2, 2018, at http://pubs.er.usgs.gov/publication/ wsp2254.

Hosman, R.L., Broussard, W.L., and Calandro, A.J., 1970, Water resources of northwestern St. Landry Parish and vicinity, Louisiana: Louisiana Department of Transportation and Development Water Resources Pamphlet no. $23,29 \mathrm{p}$

Kroes, D.E., and Kraemer, T.F., 2013, Human-induced stream channel abandonment/capture and filling of floodplain channels within the Atchafalaya River Basin, Louisiana: Geomorphology, v. 201, p. 148-156. [Also available at https://doi.org/10.1016/j.geomorph.2013.06.016.]

Louisiana Department of Environmental Quality, 2008, Environmental Regulatory Code, Title 33, Part IX, Subpart 1: Baton Rouge, Louisiana Department of Environmental Quality, accessed June 9, 2009, at https://deq. louisiana.gov/assets/docs/Legal_Affairs/33v09-201605-Water-Quality.pdf.

Louisiana Department of Natural Resources, 2017, Strategic Online Natural Resources Information System (SONRIS): Louisiana Department of Natural Resources database, accessed June 12, 2017, at http://sonris.com.

Lovelace, J.K., 1994, Water requirements for crawfish farming at selected sites in south-central Louisiana, 1992-94: Louisiana Department of Transportation and Development Water Resources Special Report no. 8, 12 p. [Also available at https://wise.er.usgs.gov/dp/pdfs/SR8.pdf.]

Lovelace, J.K., Fontenot, J.W., and Frederick, C.P., 2004, Withdrawals, water levels, and specific conductance in the Chicot aquifer system in southwestern Louisiana, 2000-03: U.S. Geological Survey Scientific Investigations Report 2004-5212, 56 p. [Also available at https://wise. er.usgs.gov/dp/pdfs/SIR_2004-5212.pdf.]

Milner, L.R., and Fisher, C., 2009, Geological characterization of the Chicot/ Atchafalaya aquifer region-Southwest Louisiana: Louisiana Geological Survey, Water Resources Series no. 4, 39 p.

Nyman, D.J., 1984, The occurrence of high concentrations of chloride in the Chicot aquifer system of southwestern Louisiana: Louisiana Department of Transportation and Development Water Resources Technical Report no. 33, 75 p. [Also available at https://wise.er.usgs.gov/dp/pdfs/TR33.pdf.]
Nyman, D.J., 1989, Quality of water in freshwater aquifers in southwestern Louisiana: Louisiana Department of Transportation and Development Water Resources Technical Report no. 42, 22 p. [Also available at https:// wise.er.usgs.gov/dp/pdfs/TR42.pdf or https://wise.er.usgs.gov/dp/pdfs/ TR42.zip.]

Sargent, B.P., 2004, Thickness of the Chicot aquifer system surficial confining unit and location of shallow sands, southwestern Louisiana: Louisiana Department of Transportation and Development Water Resources Technical Report no. 73, 29 p. [Also available at https://wise. er.usgs.gov/dp/pdfs/TR73.pdf.]

Sargent, B.P., 2011, Water use in Louisiana, 2010: Louisiana Department of Transportation and Development Water Resources Special Report no. 17, 135 p. [Also available at https://wise.er.usgs.gov/dp/pdfs/WaterUse2010. pdf.]

Saucier, R.T., 1994, Geomorphology and Quaternary geologic history of the lower Mississippi Valley, v. 1: Vicksburg, Miss., U.S. Army Corps of Engineers, U.S. Army Engineer Waterways Experiment Station, [variously paged; 414 p.]. [Also available at https://biotech.law.lsu.edu/climate/ mississippi/sausier/Sausier_Vol_I_text.pdf.]

Smoot, C.W., 1988, Louisiana hydrologic atlas map no. 3-Altitude of the base of freshwater in Louisiana: U.S. Geological Survey Water-Resources Investigations Report 86-4314, 1 sheet, accessed November 2, 2011, at https://pubs.er.usgs.gov/publication/wri864314.

U.S. Army Corps of Engineers, 2007, The Atchafalaya Basin-Explore Louisiana's great river swamp: U.S. Army Corps of Engineers, New Orleans District, accessed September 25, 2018, at https://www.mvn.usace. army.mil/Portals/56/docs/PAO/Brochures/ABFS-Brochure-27apr07.pdf.

U.S. Environmental Protection Agency, 2016, Secondary Drinking Water Standards - Guidance for nuisance chemicals, accessed April 13, 2016, at https:/www.epa.gov/sdwa/secondary-drinking-water-standards-guidancenuisance-chemicals.

U.S. Geological Survey [USGS], 2018, USGS water data for the Nation: U.S. Geological Survey National Water Information System database, accessed April 4, 2018, at https://doi.org/10.5066/F7P55KJN.

This fact sheet has been prepared by the U.S. Geological Survey (USGS), in cooperation with the Louisiana Department of Transportation and Development (DOTD), as part of a program to document water use, availability, and quality in the parishes of Louisiana. Information on the availability, past and current water use, use trends, and water quality from groundwater and surface-water sources in the parish is presented here. Previously published reports (see References Cited section) and data stored in the USGS National Water Information System (USGS, 2018) are the primary sources of the information presented here. Special thanks are given to Doug Taylor, Director, and Zahir "Bo" Bolourchi (retired), DOTD Cooperative Program with the USGS.

\section{By Maxwell A. Lindaman and Vincent E. White}

\section{For additional information, contact:}

Director, USGS Lower Mississippi-Gulf Water Science Center 3535 S. Sherwood Forest Blvd., Suite 120

Baton Rouge, LA 70816

E-mail: gs-w-lmg center director@usgs.gov

Fax: (225) 298-5490

Telephone: (225) 298-5481

Home Page: https://www.usgs.gov/centers/lmg-water/ 